\title{
The oceanic environment beneath the northwest Ronne Ice Shelf, Antarctica
}

\author{
Allan Robinson, Keit'h Makinson and Keith Nicholls \\ British Antartic Survey, Valural Environment Research Council, Cambridge CB3 OET, England
}

\begin{abstract}
ABSIRACT. Occanographic data have been obtained from beneath the Ronne Ice Shclf at a sitc on the southeastern side of a sea-floor trough, the Ronne Depression. The data consist of $\bar{j} \mathrm{~d}$ of conductivity temperature depth (CTD) profiling and a long-term temperature record from a thermistor cable. The water column was found to be composed of two layers: a cold buoyant layer of Ice Shelf Water (ISW) overlying a layer of unmodified Western Shelf Water WSW:

A change in the water column was obscrved on the last day of profiling, the WSW layer thinning, a cold intrusion appearing directly above the WSW and the ISW becoming colder. In addition, on three profiles the ISW cooled further and increased in salinity, becoming apparently statically unstable. The temperature record from the thermistor cable confirms that the ISW layer occasionally becomes colder, with greater variation in tcmperature than seen on the CTD profiles. These low temperatures and high salinities are interpreted as indicating that water containing ice crystals in suspension has been advected beneath the site.
\end{abstract}

\section{INTRODUGTION}

The interaction between the base of the Filchner and Ronne Ice Shelves and the southern Weddell Sca is thought to be an important factor in controlling the response of the West Antarctic ice sheet to climatc change (Thomas, 1985; Budd and others, 1987). It also provides a source of very cold water that contributes to the production of Antarctic Bottom Water (Seabrooke and olhers, 1971; Foldvik and Gammelsrod, 1988;, a water mass which helps drive the circulation of the decp ocean (Mantyla and Reid, 1983). An understanding of the water circulation in the cavity beneath the ice shelf is prerequisite to predicting the way the interaction between the ice shelves and the ocean will change with climate.

The principal source of evidence for the oceanographic processes occurring beneath the FilchnerRonne Ice Shelf are conventional, shipboard hydrographic surveys just offshore from the ice front (Elder and Seabrooke, 1970; Hufford and Seabrooke, 1970; Foldvik and others, 1985). For the Filchner Ice Shelf, these have revealed a pattern of relatively warm water (Western Shelf Water) flowing out, and some recirculation occurring (Carmack and Foster, 1975) in the Filchner Depression, a sea-floor trough beneath the ice shelf. The Ronne Depression (see Fig. 1) is a corresponding trough lying beneath the northwest sector of the Ronne Ice Shclf. The Ronne Depression is bounded by the Orville Coast on its northeastern side, a submarine ridge on its southwestem side and is generally shallower than the Filchner Depression. In January 1991, the ice shelf was penctrated at site $90 / 1\left(77^{\circ} 36^{\prime} \mathrm{S}, 65^{\circ} 28^{\prime} \mathrm{W}\right)$ on a flowline from the Rutford Icc Stream just south of the submarine ridge, allowing (ATI) profiling, water sampling and longterm temperature monitoring. The results of this work have been discussed by Nicholls and others (1991) and Nicholls and Jenkins (in press).

In January 1992, a hole was drilled at site 90/2 ( $76^{\circ} 42^{\prime} \mathrm{S}, 64^{\circ} 53^{\prime} \mathrm{W}$ ) which is over the Ronnc Depression. and separated from the previous site by the submarine ridge which marks the southeastern edge of the Ronne Deprcssion. The watcr-column thickness above this ridge is believed to be a few tens of metres (Pozdeyer and Kurinin, 1987), thus inhibiting cxchange of water

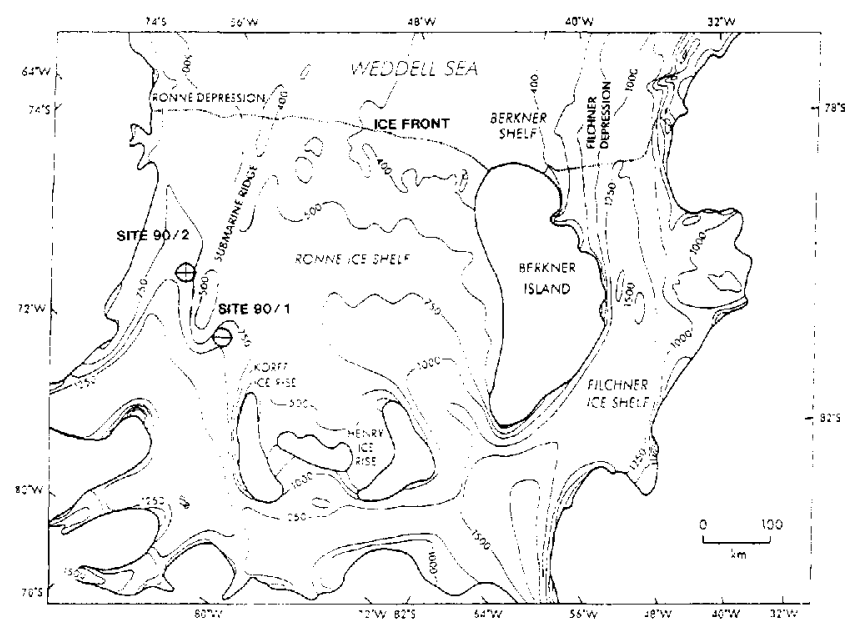

Fig. 1. Map of the southem Weddell Sea (after Pozdeyer and Kurinin, 1987), showing bathymetry in metres below sea level. The locations of the two BAS HWD siles are marked. 
between the two sites and suggesting that the oceanographic regime at site $90 / 2$ might be different from that found at site $90 / 1$.

In this paper, we describe the data collected at site 90/2 and draw conclusions about oceanic processes and circulation in the Ronne Depression.

\section{RESULTS}

A hot-nater drill (HWD) (Makinson, in press) was uscd to create an access hole and then maintain it for $5 \mathrm{~d}$. During this period, CI'l profiles and water samples were collected using a miniature combined CTD sonde and water sampler. The accuracy of the CTD scnsors was: $\pm 0.1 \mu \mathrm{sm}^{1}(\sim \pm 0.01$ practical salinity units (psu)), $\pm 0.01^{\circ} \mathrm{C}, \pm 2$ dbar. Before leaving the site, thermistor cables were deployed through the hole to monitor temperatures in both the water column and the overlying ice. Measurements made during the drilling gave an ice thickness of $541 \mathrm{~m}$. CID profiling showed the sea floor is at a pressure depth of 870 dbar with the ice-shelf base at 480 dbar.

\section{The CTD profiles}

Figure 2 shows a time sequence of potential temperature , $\Theta$ and salinity (S) profiles, with the salinities of relevant water samples marked. The water column consists of two lavers: a layer of Ice Shelf Water overlying a layer of Western Shelf Water. 'This is the first and perhaps most important result, that unmodified WSW has been found at a site $200 \mathrm{~km}$ from the ice front.

It is apparent that there is a change in the shape of both $\Theta$ and $S$ profiles during the sequence, with the lower layer becoming much thinner and a temperature inversion appearing above it. This change occurred during a gap in the profiling sequence caused by a break-down in the HWD system, and was used to split the profiles into two groups, called A and B. Three proliles marked with asterisks in Figure 2 were excluded from group $B$ because of the anomalously high salinities in the upper layer of those profiles. The watcr-sample salinities do not agree well with the related salinity profilcs. This is probably because of flushing and freezing problems with the miniature water samplers. Approximately half of the collected water-sample data was discarded because of anomalously low salinitics (varying from 33 psu to 0 psu), but the remainder were within about $0.03 \mathrm{psu}$ of the related salinity profiles. The specific causes are belicved to be failures in the pressure-compensation mechanism of the water sampler (Richards and Mclling, 1987) and inadequate flushing of the taps on the water sampler before decanting the sample, allowing contamination of some samples with fiesh water from the borehole. Other groups have experienced lack of agreement betwecn the salinity of water samples and C'lD measurements from beneath ice shelves (Foster, 1983) and in particular with this type of water sampler personal communication from F. Fahrbach). As a conscquence, we do not place much reliance on the water-sample salinity data.

Figure $3(\Theta-S$ plot with depths marked on the

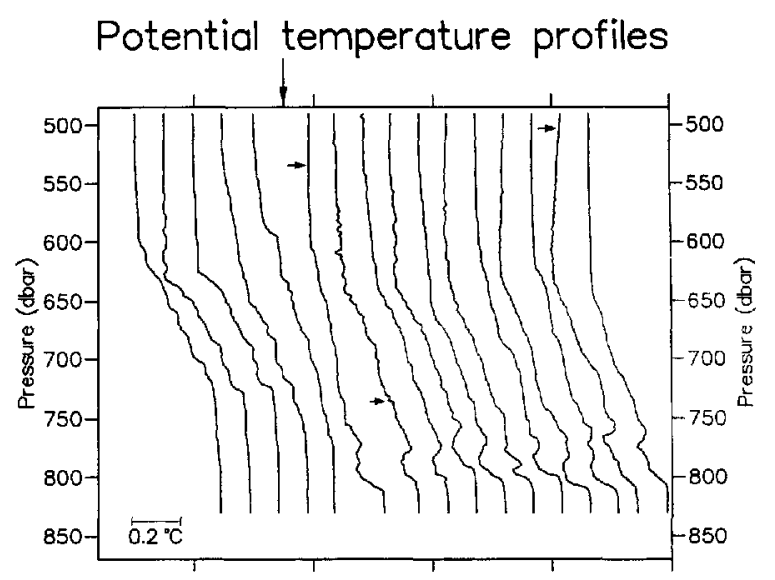

$\mathbf{a}$

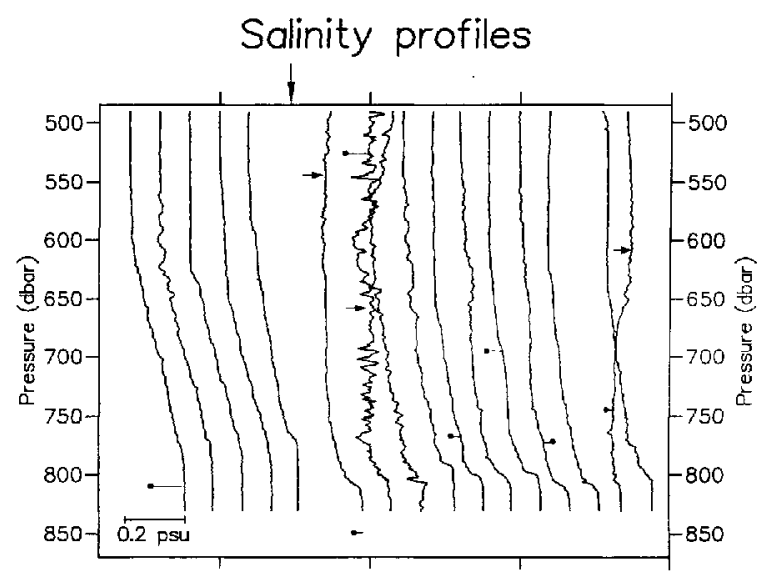

b

Fig. 2. Sequence of potential temperature and salinity profiles, showing how the structure of the water column changed over the $5 d$ the HWD hole was open. The sequence is not linear in time, and the large arrow marks a $2 d$ period in which no profiling occurred. Profiles were split into two groups $A$ and $B$ (see text) which are separaled by the $2 d$ gap. Profiles to the right of the arrow were measured on the final day of profiling. The three profiles indicated with small arrows were excluded from group B because of anomalously high salinities at the top of the weater column. a. Temperature profiles: profiles are consecutively shifted $+0.12^{\circ} \mathrm{C}$ to the right. b. Salinity profiles: profiles are conseculively shifted +0.1 psu to the right. Dots mark water-sample salinities with lines attaching them to the relevant profile. The valer-sample salinities have been shifted by the same amount as the related profile.

profiles is a $\Theta-S$ plot of the means of the profiles composing groups $\mathrm{A}$ and $\mathrm{B}$. It highlights the different $\Theta-\mathrm{S}$ characteristics of the two groups of profiles. Group $B$ has a slightly fresher and colder WSW lower layer and a slightly colder ISW upper layer than group A. 'The main difference in the shapes of the group B and group A profiles may be explained either as the intrusion of a colder water mass just above the WSW or as the replaccment of the WSW in group A with a colder, fresher and thinner layer of WSW. The latter cxplanation would suggest that the temperature inversion in group B is a transitory fcature. 


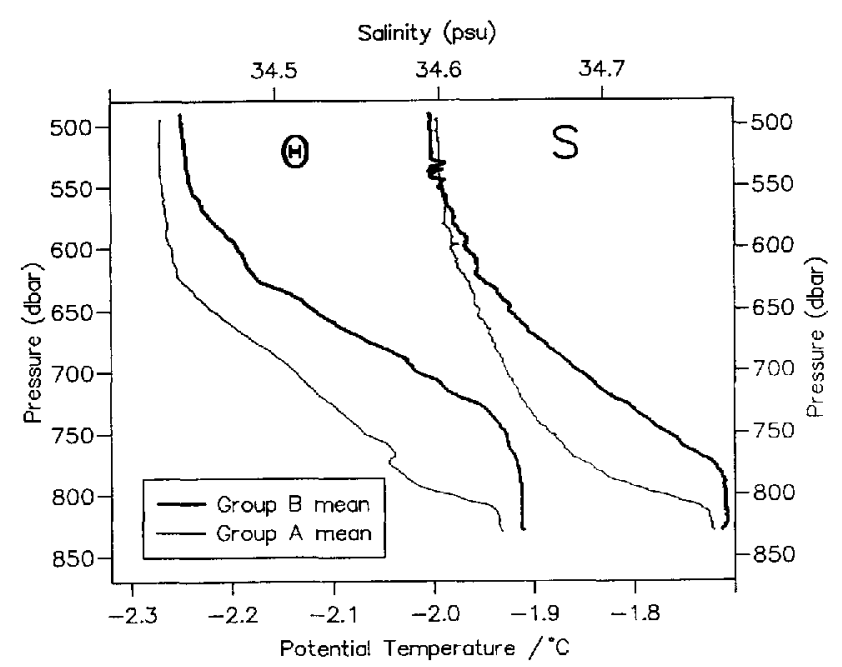

Fig. 3. Mean profiles of potential temperature and salinity for groups $A$ and $B$ (see Fig. 2). Lines on the lefthand side are potential temperature $(\Theta)$ and those on the righthand side are salinity. In both cases, group $A$ profiles are indicated by the bold lines.

\section{The "unstable" profiles}

The three profiles excluded from group $B$ are shown in more detail in Figure 4 . They are all characterized by anomalously high salinities and temperature inversions in the upper layer. The salinities shown in Figure $4 \mathbf{b}$ and $c$ are as high as those in the lower (WSW) layer, giving a large density inversion which should cause the water column to overturn vigorously. The result of such ovcrturning would be a homogenized water column which, as can be seen from Figure 2, does not happen. Bccausc overturning has not occurred, thc density inversion, implied by the CTD data, cannot be real. I'wo possible explanations for this are that the conductivity ccll on the CTD probe has produced crroncous data or there is a suspension of ice crystals present in the water column. A mechanism by which the conductivity cell can read high is not obvious, since contamination of the cell usually leads to a reduction in measured conductivity. In addition, the data show no evidence of electronic problems in the probe. The latter explanation, that there is a suspension of ice crystals in the water column, does not fit the data well either, since the temperature on all three profiles is between $0.01^{\circ}$ and $0.1^{\circ} \mathrm{C}$ above the in situ freczing point, and the presence of ice crystals in thermal equilibrium would lead to the water being at the in situ frcezing point. If wo consider the group B mean temperature profile and the in situ freezing-point profile, we find that the temperature profile of Figure $4 \mathrm{c}$ bisects them, indicating that the Figure $4 \mathrm{c}$ temperature profile would be produced by mixing constant proportions (with depth) of group B ISW with water at the appropriate pressure-freezing point. This hypothesized water mass with a temperature at the freesing point, which we will call cold ISW, could contain frazil ice (sec Foldvik and Kvinge, 1974). With this interpretation, the presence of ice crystals in the water column results from advection and mixing between two different ISW masses, in one of which ice crystals have formed. Because of the difference

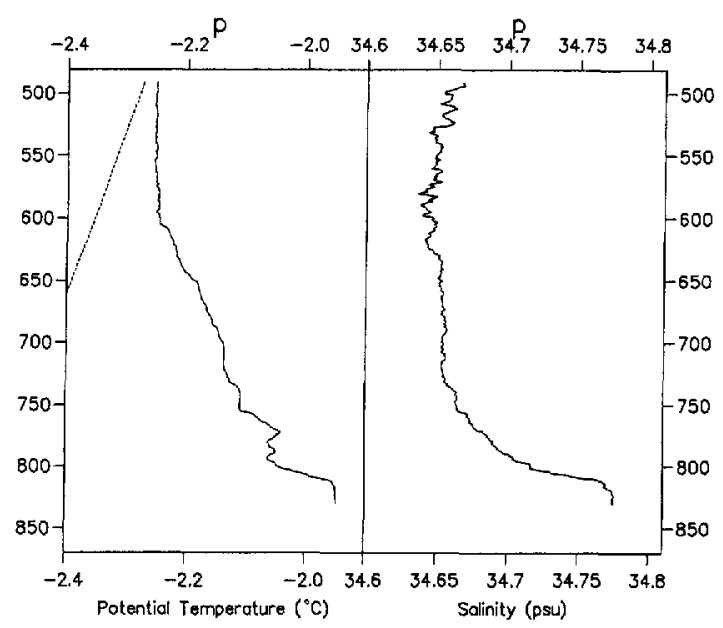

$\mathbf{a}$

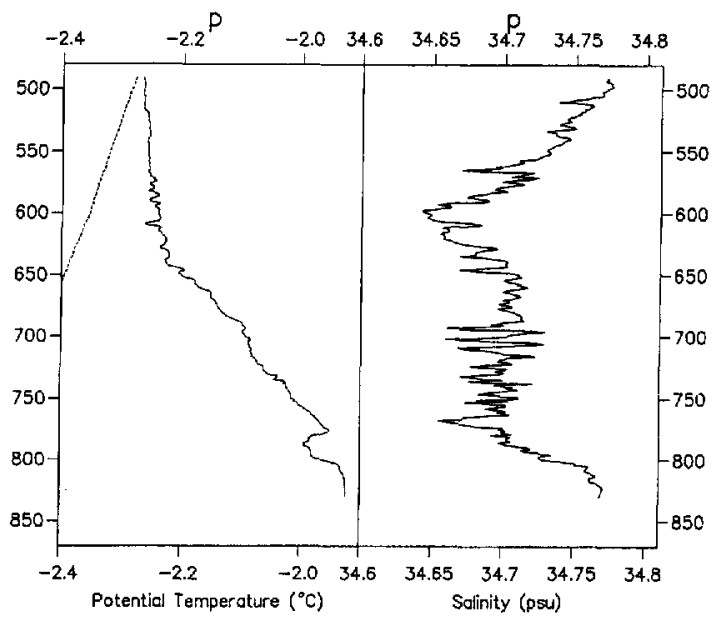

b

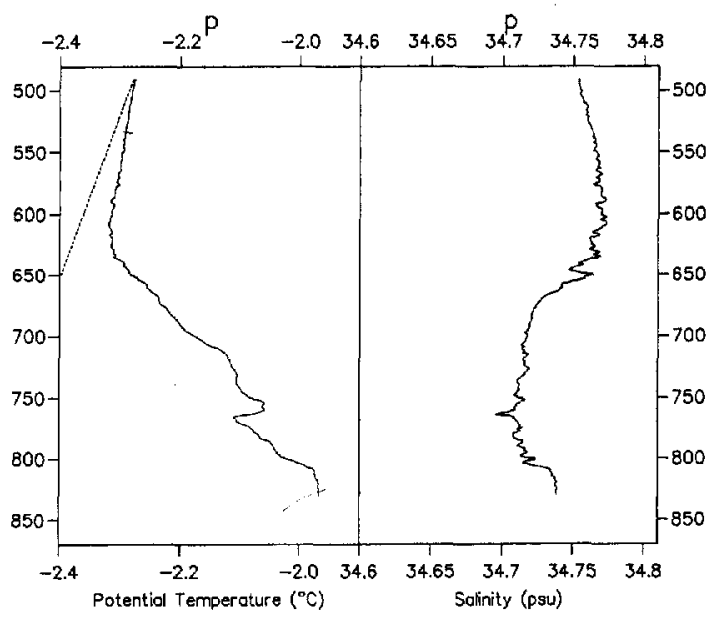

$\mathbf{c}$

Fig. 4. $\Theta$ and $S$ profiles of the three excluded profiles, with the in silu freezing point marked by the dotted line.

between turbulent and molecular thermal diffusivities. the ice crystals have not yet melted, i.e. the proportion of ice crystals in the water column beneath this site is controlled by turbulent diffusion and advection between cold ISW and group B ISW, but the time-scale for them to melt in the new composite water mass is controlled by the molecular diffusion of heat. Order-of-magnitude calculations indicate that at the bottom of the salinity 
inversions ( $\sim 600$ dbar on Figure $4 \mathrm{~b}$ and $c$ ) ice crystals will melt in a time-scale of the order of seconds, while near the ice-shelf base the time-scale will be of the order of minutes. Looking at the profiles in the context of these time-scales, it would appear that: in Figure $4 \mathrm{c}$ advection has only just ceased or is still occurring and that melt is occurring mainly at the lower edge of the intrusion; in Figure $4 b$ advection has ceased and ice crystals are in the process of melting; in Figure ta the water column above the lower layer is approximately isohaline, indicating that melt would have been going on for several minutes, removing ice from all but the very top of the water column. The noise on the salinity records may be cxplained in the upper layer by the melting of ice crystals, and below the salinity inversion by the turbulent overturning of water which the ice crystals have risen above, removing the stabilizing effect of their buoyancy. This may also explain why the salinity in the lower layer of Figure $4 \mathrm{c}$ is reduced, though the limited data prevent a comprehensive explanation of such a complicated process.

Since the profle in Figure 4c appears to show the most recent signs of advection, we can try to calculate the proportion of ice that would be required to stabilize the salinity inversion. Assuming the composite water mass has a bulk-density profile less than or equal to the average profile for group B, because overturning does not take place, the proportion of ice crystals must be greater than $1.2 \%$ by volume. Using the salinity of the water below the salinity inversion as a bulk salinity gives proportions of ice crystals of 1,6 and $2 \%$, respectively, for Figure $4 c$ and $b$, though this will have been increascd if mixing with water from the pycnocline has occurred. If we then assume that ice crystals mix in the same way as heat, and that cold ISW is at the in situ freezing point, the concentration of ice crystals in cold ISW would have been greater than $3 \%$ by rolume.

\section{The thermistor cable temperature record}

Immediately after the deployment of the thermistor cable, it was logged for $2 \mathrm{~d}$ at $5 \mathrm{~min}$ intervals before being left for the winter with a logging interval of $80 \mathrm{~min}$. The $2 \mathrm{~d}$ record is shown in Figure 5 . The variations in temperature of each thermistor indicate that the cable is swinging in the tidal currents with the thermistors passing up and down through the water column. Simple hydrodynamic modelling (e.g. Steele and Morrison, 1992) of the cable's behaviour suggests that the currents have maximum speeds of around $0.5 \mathrm{~ms} \mathrm{~s}^{1}$ and minimum speeds of under $0.1 \mathrm{~ms}{ }^{l}$, assuming no variation in velocity through the water column. These values are in broad agreement with velocities measured at the ice front (Gammelsrod and Slotsvik, 1981). The record also demonstrates the occasional presence of a colder water mass, when the temperature of the whole water column drops, and the upper layer reaches temperatures lower than seen in the CTD profiles. Figure 5 shows the recovery from one such "cold event" takes $2-3 \mathrm{~h}$.

Figure 6 shows that "cold events" occur with a period of about $100 \mathrm{~h}$. The only similar behaviour seen in the CTD profiles is from the three temperature profiles in Figure 4 , which are depressed by $\sim 0.01-0.02^{\circ} \mathrm{C}$ below the mean profile, over the whole water column.

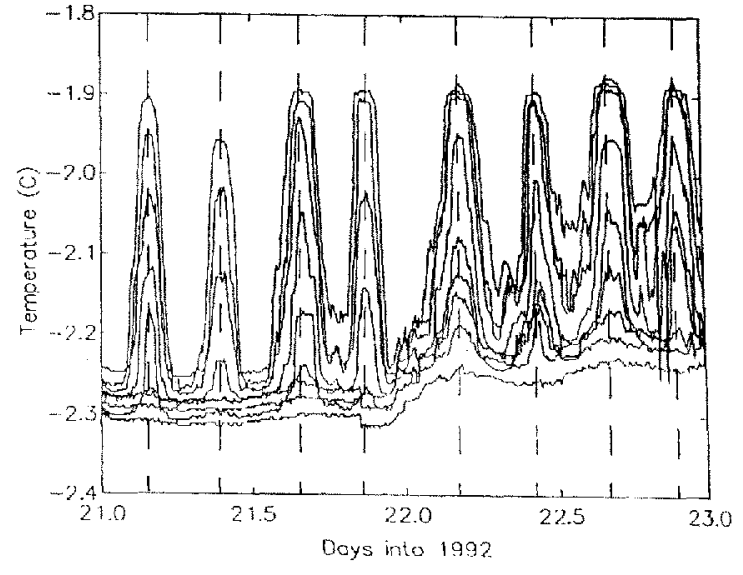

Fig. 5. 2 section of the therrnistor cable record. The record starts 4 h after the final CTD profile (Fig. 2). Temperatures were logged at 5 min intervals. Each solid line represents the record from one of the ten thermistors, which were evenly spaced at $35 \mathrm{~m}$ intervals down the cable, starting $40 \mathrm{~m}$ below the ice-shelf base. Dashed lines mark times zehen the cable is believed to be hanging vertically in the water column.

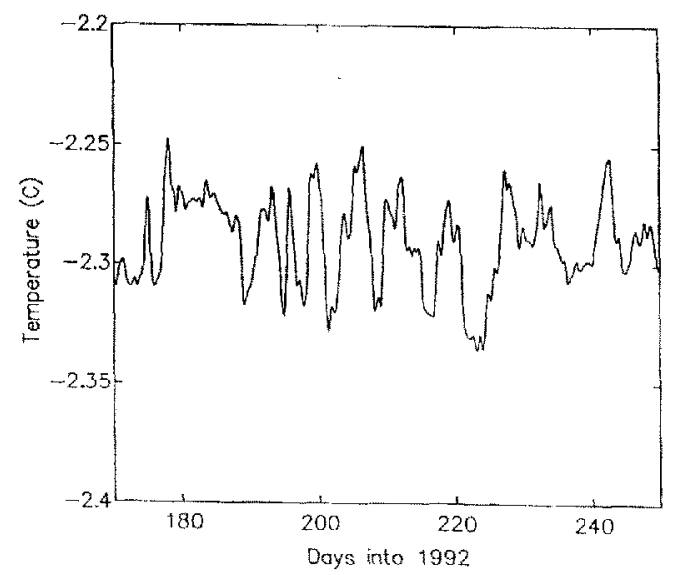

Fig. 6. $70 d$ temperature record from the uppermost thermistor, with a logging interval of $80 \mathrm{~min}$. The record has been low-pass. filtered with a cut-off of $24 \mathrm{~h}$ to remove any tidal signal.

\section{DISGUSSION}

The most general result from this work has been the observation of unmodified WSW below the ice shelf at a considerable distance from the ice front. The ided of shelf water flowing underneath the ice shelf was originally postulated by Seabrooke and others (1971) and expanded upon by Jacobs and others (1979).

In addition, the data show that the water column exists in two different conditions, as defined by groups $A$ and $B$ above. This is seen on both the CTD data and the thermistor record: $8 \mathrm{~h}$ bcfore the deployment of the thermistor cable, the CTD profiles indicate that the characteristics of the water column fall within group $B$. The short thermistor record shows that temperature of the water column is initially colder, with upper-layer temperatures of about $-2.30^{\circ} \mathrm{C}$. Temperatures this low 
were only seen on the three profiles excluded from group. B. After a day of monitoring, the temperature of the upper layer increased to $2.24^{\circ} \mathrm{C}$. This is larger than the temperature difference between the two groups of $\mathrm{C}^{\prime} \mathrm{I} D$ profiles. However, a slight cooling trend can be seen on the first day of the short record (Fig. 5), and the longer record (Fig. 6) shows that the changes from colder water to warmer water are not necessarily the same size.

The longer thermistor rccord (Fig. 6) shows that periodically the tcmperature of the upper layer drops to temperatures significantly lower than group A or B. Similar behaviour is secn on threc CTD profiles which suggest that the water column may contain ice crystals in suspension. The periodic appearance of low temperatures indicates that a mechanism exists which can advect water across the Ronne Depression and that this mechanism is not tidal. The geometry of the Ronne Depression suggests that this cold water originates from northeast of site $90 / 2$. The existence of marine icc at the base of the ice shelf adjacent to the Orville Coast may indicate that cold ISW comes from that side of the depression.

\section{CONCLUSIONS}

The work at this site has revealed a water column consisting of ISW overlying unmodificd WSW, with tidal currents which are strong compared with site $90 / 1$ where there was little indication of tidal motion (Nicholls and others, 1991). T'he watcr column exists in more than one state, with changes in the thickness and properties of the ISW and WSW layers being observed. The advection of a cold water mass containing ice crystals in suspension is suggested by three C'ID profiles, and this is consistent with the thermistor-cable record in which periodic drops in the temperature of the water column can be seen. This cold, ice-bearing water mass is suggested to be located on the northeastern Orville Coast) side of the Ronne Depression.

\section{ACKNOWLEDGEMENTS}

The authors express thcir gratitude to the British Antarctic Survey's field operations staff and $\Lambda$ ir Lnit, and especially to J. Sweeney and S. Davis for their assistance at the drill site.

\section{REFERENCES}

Budd, W. F., J. MacInnes, D. Jenssen and 1. N. Smith. 1987. Modelling the response of the West Antaretic Ior Sheet to a climatic waming. In Van der Vecn, C.J. and J. Oerlemans, eds. Dynomics of the II'st Antartic Ice Sheet. Dordrecht, Reide].

Carmack, E. C. and T.D. Foster. 1975. Circulation and distribution of oceanographic properties near the Filchner Ice Shell: Dep-Sea Res. 22. $77-90$.

Elder, R. B, and J. M. Seabrooke. 1970. Oceanography of the Meddrll Sca, January-March, 1968. ISCG Ocennographic Repont . Wi. 30 CG $373-30 ;$

Foldvik, $A$, and T. Gammelsrod. 1988. Notes on Southern Occan hydrography, sea-ice and bottom water formation. Pataogengs. Palaenclimatol. Palaenerd., 67, 3-17.

Foldvik, A. and T.Kvinge. 1974. Conditional instability of sea water at the freezing point. Decp-Sen Res., 21, 169178.

Foldvik, A., T. Gammelsrod and 'I. Torresen. 1985. Physical oceanography studios in the Weddell Soa during the Nomegrian Antarctic Rescarch Expedition 1978/79. Polar Res.. 3 2), 195-207.

Fostcr, T. D. 1983. The trmperature and salinity finc-structure of the ocean under the Ross Ice Shelf. 7. Geophy. Res., 88 C4), 2556-2564.

Gammelsrod, T. and N. Slotsvik. 1981. Hydrographic and current measurements in the southern Weddell Sea 1979/80, Polnforschung. $50(1), 101 \cdots 111$.

Hufford, G. L, and J.M. Seabrooke, 1970. Oceanography of the Weddell Sea in 1969 IWSOE. USCG Oceanographic Repor No. 31.

Jacobs, S. S., A. I. Gordon and J. L. Ardai, Jr. 1979. Girculation and melting beneath the Ross Ice Shelf. Science, 203(4379), 439-443.

Matinson, K. 1994. The BAS hot water drill: development and current design. Cold Reg. Sci. Terhnol., 22, 121-132.

Mantyla, A. W. and J. L. Reid. 1983. Abyssal characteristics of the world occan's waters. Deep-Sea Res., 30, 805-833.

Nicholls, K. W. and A. Jenkins. 1993. Temperature and salinity bencath Runne Ice Shelf; Antarctica. 7. Geophrs, Res, 98 C12 22.5j322.568.

Nicholls, K. W., K. Makinson and A.V. Robinson. 1991. Occan circulation beneath the Ronne Ice Shelf. Nature, 354,6530), 221-223.

Pozdeyes, V.S. and R.G. Kurinin. 1987. New data on the ice-sheet morphology. bedrock and bottom relief in the southern Nieddell Sea basin (West Antarctica). Antarktika, 26, 66-71. In Russian.

Richards, D. L. and II. Melling. 1987. An oceanographic bottle system for CTD caliluation. OCEA 15 87. 183-187.

Seabrooke, J. M., G. L. Hufford and R. B. Elder. 1971. lormation of Antarctic bortom water in the Neddell Sea. 7. Gephys. Res., 769. 2164-2178.

Stecle, M. and J.H. Morison. 1992. Obtaining smooth hydrographic profiles from a buoy deployed in sea-ice. 7 . Atmo. Orem. Toth. 9. $812-826$.

Thomas, R.H. 1985. Responses of the polar ice sheets to climatic warming. In Glaciers, ice sheets and sea level: effects of a CO.,-induced cimatic change. DOE/ER/60235-1, Washing10n DC, L.S. Departnent of Energy, 301-316.

The accuracy of references in the text and in this list is the responsibility of the authors, to whom queries should be addressed. 